\title{
Using Digital Marketing to Develop Marketing Strategy for Fish Farmer Group Products in Jehem Village
}

\author{
Putu Vidya Shania Devia), Kadek Devi Kalfika Anggria Wardani, Dewa Ayu Putu \\ Adhiya Garini Putri
}

\author{
Program Studi Akuntansi, Universitas Pendidikan Nasional, Denpasar, Indonesia \\ a)Corresponding Author: vidyashania13@gmail.com
}

\begin{abstract}
Fish Farmer Group "Mina Kumala Sari" is a fish farming group located in Jehem Village, Tembuku District, Bangli Regency and is engaged in fisheries, especially koi fish. Based on observations, it is known that this group still has problems in marketing the product. By using digital marketing through social media, it is hoped that they can reach the target market of the "Mina Kumala Sari" Fish Farmer Group. The purpose of this community service is to find out the use of digital marketing as a marketing strategy for the cultivation of the Fish Farmer Group "Mina Kumala Sari" Jehem Village. The implementation method begins at the observation stage, then conducts interviews with the group leader to gather information, followed by a literature study to collect data from literature and the last stage is documentation in the form of photos and videos. Based on the results of the service, it can be concluded that utilizing social media as a means to market products is quite effective because before the promotion was carried out many people did not know the existence of this group and after promotion through social media and direct and online promotions with groups or communities of ornamental fish lovers caused the Farmers Group Fish "Mina Kumala Sari" is increasingly recognized by the wider community.
\end{abstract}

Keywords: Digital marketing, marketing strategy, cultivation results

\section{INTRODUCTION}

The Covid-19 pandemic has caused the Indonesian government to issue a Large-Scale Social Restriction or PSBB policy which causes economic activity to slowdown (Trulline, 2021). Business owners must quickly adapt to the implementation of social distancing, because it greatly affects major changes in consumer behavior trends in shopping (Fadly, 2020). Businesses who use e-commerce will enjoy significant business advantages in terms of revenue, employment opportunities, innovation and competitiveness (Naiman et al., 2020). However, there are still many business people who have not implemented digital media because they do not understand how big the impact is on their business. There must be proper guidelines to achieve the desired target so that digital marketing can be realized through social media (Subawa et al., 2021).

Based on observations in Jehem Village, it was found that this problem was also experienced by the Fish Farmer Group "Mina Kumala Sari" where this group in the marketing process was still using conservative techniques such as word of mouth promotion, distributing brochures, and advertising on the radio. where this method is certainly less effective because it costs more.

Fish Farmer Group "Mina Kumala Sari" is a fish farming group that was founded in 2006 located in Jehem Village. Jehem Village is a village located in Tembuku District, Bangli Regency where the majority of the Jehem Village community are farmers and artisans of sanggah. Since 2004 fish farming has started and is in demand by the people of Jehem Village because fish farming is quite promising so it has been practiced until now.

Fish Farmer Group "Mina Kumala Sari" is engaged in fisheries, especially ornamental fish such as koi fish. Due to its location around rice fields and road access that can only be reached by motorbike, it makes it difficult for buyers to reach it. In addition, the marketing system carried out by the "Mina Kumala Sari" Fish Farmer Group is still not optimal, either through marketing areas or social media. Therefore, it is necessary to re-emphasize the use of digital marketing, 
where the main target is to increase sales turnover and product branding which will later increase business competitiveness.

Business people who are hindered by obstacles with the lack of knowledge of digital marketing and electronic commerce require the public to be technology literate so that they require business people to take part in training activities to be able to take advantage of internet and social networking technology as a medium in running a business. (Awali, 2020). In the midst of a pandemic, digital marketing is becoming increasingly important in order to open up new opportunities so that businesses can continue to grow. Digital marketing consists of interactive and integrated marketing in order to facilitate interaction between producers and potential consumers (Mustika, 2019). Moreover, digital marketing is also able to reach the target market more accurately, and efficiently in evaluating performance. Marketing via social media is much cheaper and saves time (Sunardi et al., 2020).

Digital marketing has many advantages compared to conventional marketing strategies (offline marketing), including in terms of measuring the success of a strategy. In addition, potential consumers can search and get product information only by exploring the virtual world (Irfani et al., 2020). Digital marketing is also able to reach the target market more accurately, cost-efficiently and able to evaluate performance more quickly.

Digital marketing-based strategies need to be applied in the digitalization era in order to achieve goals in a faster and more precise way. Digital marketing describes the main users of digital technology to support the marketing function of an organization. In organizations that understand the function of marketing, digital techniques are combined with traditional marketing activities (Alicia, 2020).

By using digital marketing, it is expected to be able to reach the target market of the "Mina Kumala Sari" Fish Farmer Group and also be more efficient in terms of costs, besides that it can also highlight the uniqueness and advantages of the "Mina Kumala Sari" Farmer Group compared to other farmer groups through blogs, websites, e-mail, adwords, and various social media networks.

Based on those background, the purpose of this community service activity is to utilize digital marketing as a marketing strategy for the "Mina Kumala Sari" Fish Farmer Group Products in Jehem Village. This is important to discuss because the use of digital marketing in the form of video promotions and posters has a major role in increasing sales and business competitiveness. In addition, with online and direct promotions with representatives of groups/communities of ornamental fish lovers, it is expected to be able to have a positive impact on the "Mina Kumala Sari" Fish Farmer Group.

\section{METHOD}

This community service activity was carried out in Banjar Tingkadbatu, Jehem Village, Kec. Tembuku, Kab. Bangli through the use of digital marketing as a marketing strategy for fish cultivation at the "Mina Kumala Sari" Fish Farmer Group where social media is used as a means to promote product results by making posters and promotional videos.

There are several methods used in this community service activity.

1. Observation Method

This method is carried out by coming directly to the location of the "Mina Kumala Sari" Fish Farmer Group to seek information about the group. This method is used to identify strengths and weaknesses so that marketing strategies are precisely targeted

2. Interview Method

The interview method was conducted with the group leader to obtain information about the problems faced by the group related to less-than-optimal product marketing.

3. Literature Study Methods

Using these method, the author collects data sourced from literature and references to articles and journals related to the scope of data regarding the use of digital marketing as a 
marketing strategy, besides that, previous research is also used by the author to deepen the research.

4. Social Approach Method

The use of this method is focused on two main activities. First, to conduct socialization with one of the youth and the surrounding community as well as representatives of the community/group of ornamental fish lovers directly and online about what are the benefits of digital marketing using social media. And also promote products where the facilities used are posters and videos for promotion of the "Mina Kumala Sari" Fish Cultivation Group in Jehem Village.

Second, provide education on how to use social media to promote a product. Starting with making posters and promotional videos, then what should be included in the posters and promotional videos and interesting captions when uploading posters and promotional videos on social media to attract consumers.

More clearly the four methods above will be applied to the flow of community service activities as shown in Figure 1. The activities carried out focus on digital marketing, especially in promoting the "Mina Kumala Sari" Fish Farmer Group by means of posters, videos and photos.

\section{RESULTS}

This community service activity lasted for approximately 45 days, where the observation process until the promotion process lasted for 3 weeks and got results in the form of making posters and promotional videos as well as good community participation after the promotional activities took place.

a. Promotional Posters and Videos

The author made posters and videos to promote the "Mina Kumala Sari" Fish Farming Group in Jehem Village. In the poster there is brief information about the group starting from the address, facilities, price of seeds and photos of koi fish. In addition to posters, the author also made a promotional video containing an overview of the "Mina Kumala Sari" Fish Cultivation Group. Besides that, it also explained about the types of koi fish that were cultivated, facilities in the form of ponds for fishing and the environment around the fish pond area.

b. Community Participation

Based on the results of community service activities, it can be seen that previously the general public did not know information about the "Mina Kumala Sari" Fish Farmer Group because most of the general public outside Jehem Village often bought ornamental fish products, especially koi fish seeds in the Ubud area, Gianyar. After the promotion was carried out by posting videos and posters through social media and conducting direct and online socialization with representatives of the community/group of ornamental fish lovers, it can be seen that there was a surge in consumers who started visiting the "Mina Kumala Sari" Fish Cultivation Group to buy fish seeds and pass the time. spare time by fishing in the fishing pond that has been provided.

\section{DISCUSSION}

Based on the results of this community service where previously the author conducted socialization as well as promotion with the help of the head of the Fish Farmer Group "Mina Kumala Sari" and the local community using posters and videos promoted through social media. Community participation in promoting posters and videos regarding the "Mina Kumala Sari" Fish Farmer Group in Jehem Village was welcomed and assisted by several parties such as the ornamental fish lover community and local youths to assist in promoting the posters and videos that the author had previously made. . After the promotion through social media, there was an increase in the number of consumers who came to visit the "Mina Kumala Sari" Fish Farmer Group to buy koi fish seeds and fish. 
In addition to utilizing digital marketing, there is a need to increase the creation of promotional content and upload promotional content as often as possible on social media. Because the attractive promotional content and the intensity of the uploaded content make consumers interested in visiting the location of the "Mina Kumala Sari" Fish Farmer Group. For this reason, in the future it is necessary to conduct training to create promotional content, be it photos, videos, and posters to attract consumers who come.

\section{CONCLUSIONS AND RECOMMENDATIONS}

Community service activities by utilizing digital marketing as a marketing strategy are quite effective because it can be seen that previously the general public did not fully know the existence of the Fish Farmer Group "Mina Kumala Sari" but after promotion through social media and introducing it to several groups/communities of ornamental fish lovers, it caused The Fish Farmer Group "Mina Kumala Sari" is increasingly being recognized by the wider community. "Mina Kumala Sari" Fish Farmer Group has very good potential. In the future it can be used as an educational tour, especially in cultivating fish and improving facilities in the form of adding ponds for fishing because it can be seen that the current pandemic makes people tired if they stay at home.

\section{ACKNOWLEDGMENTS}

The author would like to thank Mr. I Gede Artawan as the Head of the Fish Farmer Group "Mina Kumala Sari" who has provided the opportunity for the author to carry out community service activities at the location of his fish pond in Jehem Village.

\section{REFERENCES}

Alicia, T. S. (2020). Strategi Pemasaran Melalui Digital Marketing pada PT Bhumi Visatanda Yogyakarta. Laporan Magang. https://dspace.uii.ac.id/bitstream/handle/123456789/23790/17211077 Tarita Syavira Alicia.pdf?sequence $=1$

Awali, H. (2020). Urgensi Pemanfaatan E-Marketing Pada Keberlangsungan Umkm Di Kota Pekalongan Di Tengah Dampak Covid-19. BALANCA : Jurnal Ekonomi Dan Bisnis Islam, 2(1), 1-14. https://doi.org/10.35905/balanca.v2i1.1342

Fadly. (2020). Membangun Pemasaran Online dan Digital Branding Ditengah Pandemi Covid-19 1. 5, 213-222.

Irfani, H., Yeni, F., \& Wahyuni, R. (2020). Pemanfaatan Digital Marketing Sebagai Strategi Pemasaran Pada UKM Dalam Menghadapi Era Industri 4.0. 3(3), 651-659.

Mustika, M. (2019). Penerapan Teknologi Digital Marketing Untuk Meningkatkan Strategi Pemasaran Snack Tiwul. JSAl (Journal Scientific and Applied Informatics), 2(2), 165171. https://doi.org/10.36085/jsai.v2i2.352

Naiman, R. J., Wardhana, M. W., Haryanto, R., \& Pebrianto, A. (2020). Penerapan Digital marketing Sebagai Strategi Pemasaran UMKM. Jurnal IMPACT: Implementation and Action, 2(2), 39. https://doi.org/10.31961/impact.v2i2.844

Subawa, S., Yansen, M., Agung, A., Wirajaya, M., \& Rahmadi, R. (2021). Penerapan Digital Marketing Arak Bali Produksi Desa Besan Application of Digital Marketing in "Arak Bali " produced by Besan Village. 5(3), 338-344.

Sunardi, N., Sarwani, Nurzaman, E., Pranoto, \& Et.al, R. B. H. (2020). Peran Digital Marketing Dalam Upaya Meningkatkan Pendapatan UKM yang Berdampak Pada Kesejahteraan Masyarakat di Kab. Purwakarta di Tengah Pandemi Covid-19. 2(1), 58-67.

Trulline, P. (2021). Pemasaran Produk UMKM Melalui Media Sosial dan E-Commerce. Jurnal Manajemen Komunikasi, 5(2), 259. https://doi.org/10.24198/jmk.v5i2.32746 


\section{APPENDIX}

Table 1. Before vs After Implementation Comparison

\begin{tabular}{|c|c|c|}
\hline No & Before & After \\
\hline 1 & $\begin{array}{l}\text { The public does not yet know about } \\
\text { the information about the Fish Farmer } \\
\text { Group "Mina Kumala Sari". }\end{array}$ & $\begin{array}{l}\text { The public began to know information } \\
\text { about the "Mina Kumala Sari" Fish Farmer } \\
\text { Group through social media where the } \\
\text { public can view the "Mina Kumala Sari" } \\
\text { Fish Farmer Group's social media account } \\
\text { to get information }\end{array}$ \\
\hline 2 & $\begin{array}{l}\text { Most of the people outside Jehem } \\
\text { Village do not know about the "Mina } \\
\text { Kumala Sari" Fish Farmer Group } \\
\text { because previously people often } \\
\text { bought koi fish seeds in the Ubud } \\
\text { area, Gianyar Regency. }\end{array}$ & $\begin{array}{l}\text { After promoting through posters and } \\
\text { videos, people became interested in } \\
\text { visiting the Fish Farmer Group "Mina } \\
\text { Kumala Sari" to buy fish seeds and } \\
\text { refreshing by fishing in the pond because } \\
\text { the location of the Fish Farmer Group } \\
\text { "Mina Kumala Sari" was around the rice } \\
\text { fields. }\end{array}$ \\
\hline
\end{tabular}
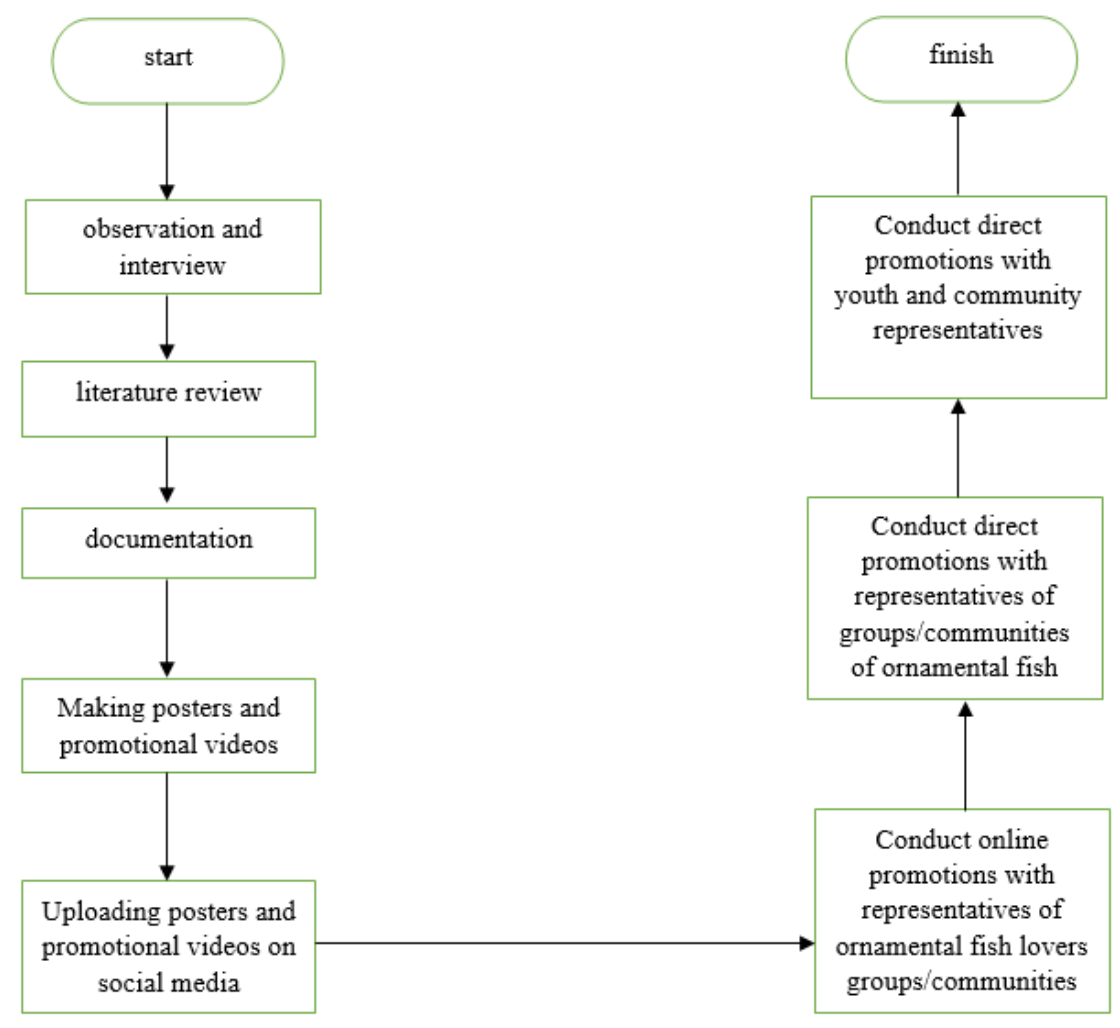

Figure 1. Activity plan 


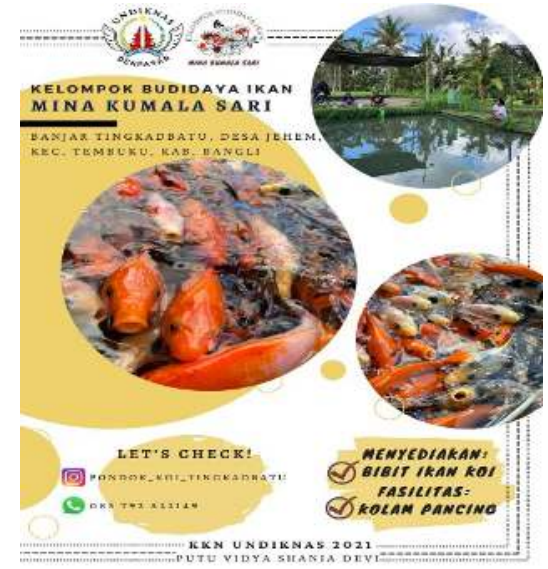

Figure 2. Promotional posters
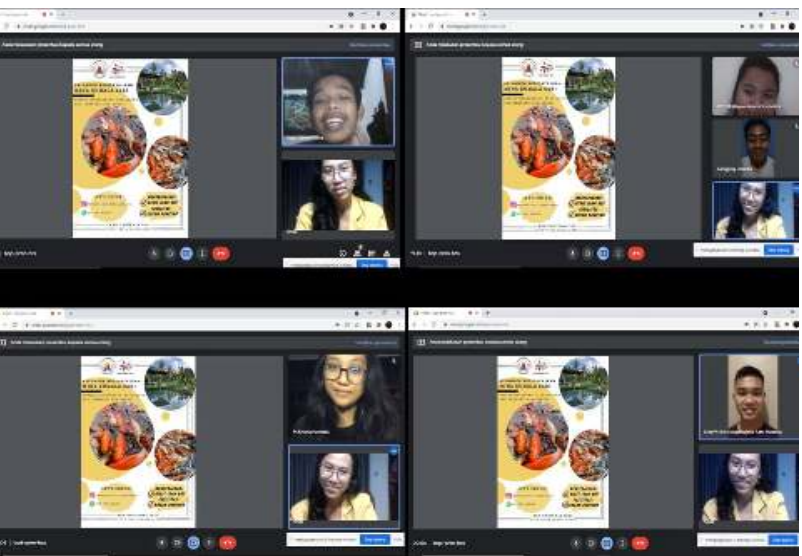

Figure 4. Online Promotion with Ornamental Fish Lover Groups/Communities

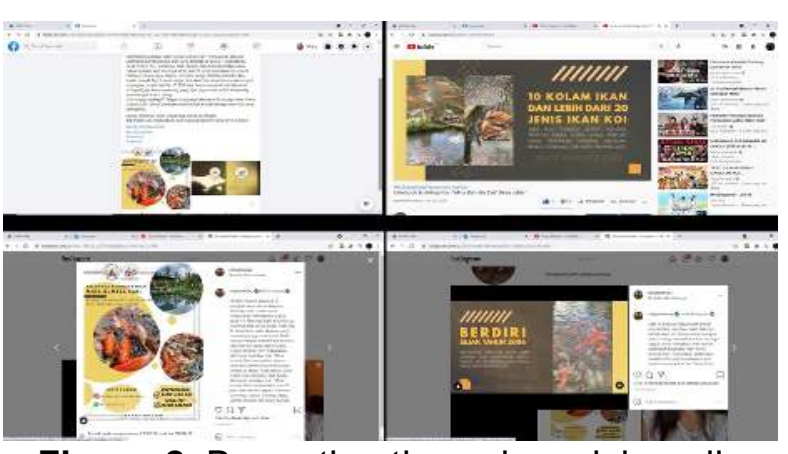

Figure 3. Promotion through social media

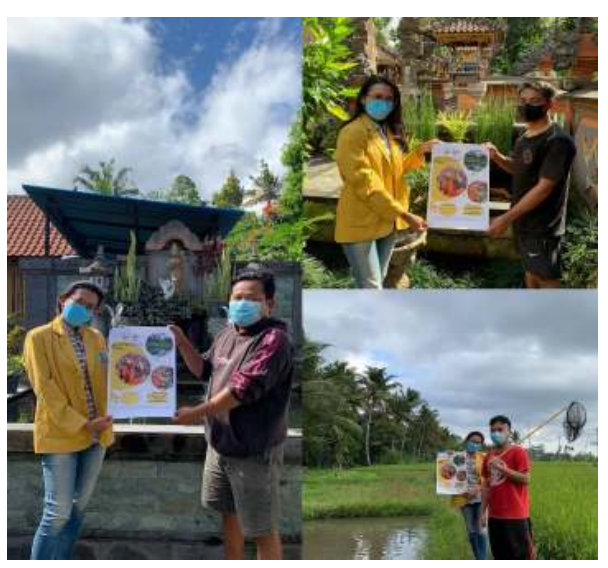

Figure 5. Direct Promotion with Representatives of Ornamental Fish Lovers Groups/Communities, Local Communities, and Youth Representatives from Banjar Tingkadbatu, Jehem Village

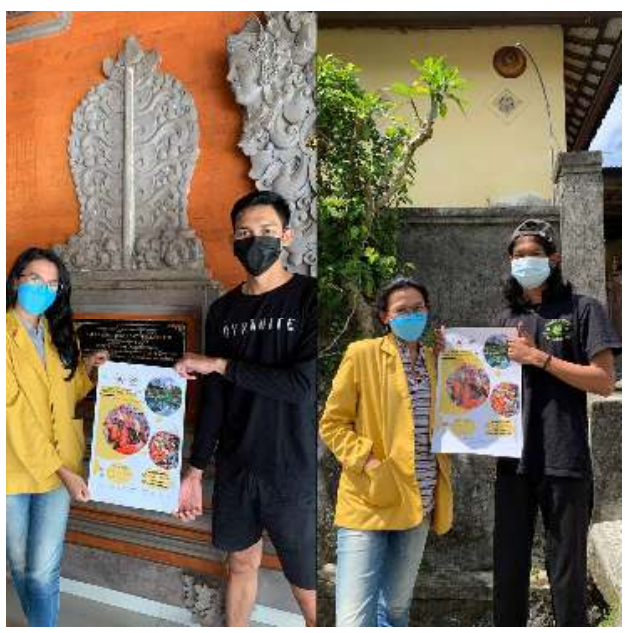

Figure 6. Direct Promotion with Local Communities and Youth Representatives from Banjar Tingkadbatu, Jehem Village 